\title{
Ke vzniku a recepci Bassova protektorátního románu
}

Erik Gilk

\begin{abstract}
On the Genesis and Critical Reception of the Protectorate Novel by Eduard Bass

The present paper deals with the most extensive novel by Eduard Bass (1888-1946) Cirkus Humberto published in 1941. Although the novel was later produced as an operetta, a drama, a radio play and a TV series, literary historians have not inquired into this popular novel. On the other hand, there are many critical reviews of the period which document that the critical discussion was possible even in the third year of German occupation during the World War II. The study focuses on the genesis and critical reception of the novel and also attempts to interpret it as an update of the ideals of the Czech national revival. It is supposed that the conception of European history created by German philosopher Johann Gottfried Herder was encoded in the novel. His theory on a positive future of Slavonic nations had a significant impact on the beginnings of the Czech national revival. A thematic connection between Cirkus Humberto and the first fiction Klapzubova jedenáctka by Bass can be also found here (1922).
\end{abstract}

\section{KEYWORDS}

Czech literature, World War II, social novel, Johann Gottfried Herder, philosophy of history, Eduard Bass, Cirkus Humberto.

\section{KLÍčovÁ SLOVA}

Česká literatura, období protektorátu, společenský román, Johann Gottfried Herder, filozofie dějin, Eduard Bass, Cirkus Humberto. 


\section{Úvodem}

Vrcholný a vlastně jediný román Eduarda Basse Cirkus Humberto (1941) je dnes považován za klasické dílo naší moderní prózy, které bezpochyby náleží do kánonu české literatury 20. století a přetrvává v kulturním segmentu naší kolektivní paměti. K dnešnímu datu se román dočkal třiadvaceti vydání (za okupace hned pěti reedic), v roce 1956 byl zpracován jako opereta Jaroslava Křičky, v sezoně 1978/1979 byl dramaticky inscenován v kladenském divadle, o rok později jej Jiří Horčička adaptoval jako rozhlasovou hru a konečně v roce 1988 podle něj natočil režisér František Filip úspěšný televizní seriál o dvanácti epizodách. ${ }^{1}$

Přesto je literárněhistorická recepce Bassova opus magnum spíše neuspokojivá a rozhodně neodpovídá jeho významu a poměrně širokému spektru bezprostřední kritické recepce. Román uspěl i v tehdejších literárních anketách, vedle Knihy roku Lidových novin jednoznačně zvítězil rovněž v anketě Nedělního listu nazvané „Za této války múzy mlčí“. Záhy po válce vycházely spíše vzpomínky či informační zprávy, jež v souvislosti s Bassovým předčasným úmrtím v prvním poválečném roce nesou podíl na konstrukci jakési aureoly kolem jeho nejrozsáhlejší prózy.

\section{Geneze románu, okolnosti vzniku}

Bass si sice vedl velký zápisník s názvem Naše kronika (tj. kronika jeho společného života s manželkou Táňou Bassovou-Schmidtovou), jehož výbor pořídily knižně editorky Marie Krulichová a Milena Vinařová v roce 1985 (BASS 1985), avšak pravidelné zápisky končí rokem 1938.

V Bassově pozůstalosti zůstal zachován kromě rukopisu románu rovněž soubor př́ípravných textů a poznámek $\mathrm{k}$ tomuto dílu. Téma autora lákalo dávno a první povídky s cirkusovými náměty napsal už ve dvacátých letech. Okouzlení cirkusovou atmosférou - v období umělecké avantgardy dvacátých let až módní - vyústilo v hluboký zájem o všechny podrobnosti života cirkusových umělců, o jejich práci a o historii cirkusu vůbec. Ostatně už v souboru Šest děvčat Williamsonových (1930) publikoval dvě cirkusové povídky, původně otištěné v Lidových novinách v letech 1921 a 1924. Tyto texty - jmenovitě Vyprávění hrá-

1) Filmový producent Miloš Havel plánoval natočit filmovou adaptaci Bassova románu již za protektorátu a s realizací počítal těsně po válce. Prací na scénosledu Cirkusu Humberto byl v roce 1944 pověřen Jan Drda. Viz WANATOWICZOVÁ 2013: 224, 273, 340. 
če na xylofon a Vzpomínka malíře stínoher - pak přepracoval pro soubor Lidé $z$ maringotek (1942) s podtitulem Příběhy jedné noci, který v prologu dedikoval „čtenářrom knihy Cirkus Humberto“, a nadto uvedl, že jej vytvořil ze zbytků materiálu připraveného pro tento román.

Autor - věrný své systematičnosti a důkladnosti - si zavedl rozsáhlou abecedně řazenou kartotéku s podrobnými výpisky a poznámkami o cirkusovém prostředí, různých výkonech, o osudech a přibězích lidí kolem cirkusu. Proti romantizujícím představám o cirkuse a lidech kolem něj podle autora stojí skutečnost, tedy těžká a nebezpečná práce, podmíněná vědomostmi a tvrdě získanou dovedností. Například oddíl poznámek o akrobacii zakončil Bass výrokem plným úcty: „Na hrazdě: hymna krásy. Bez tíže. Nemíchat do toho komiku!“ (IBID.: 16)

Kromě této kartotéky měl Bass pro Cirkus Humberto připraven soupis charakteristik jednotlivých postav románu, rovněž abecedně seřazený. Hrdiny charakterizoval stručně: detailem, zvláštností v jednání či vzhledu, krátkým dialogem či výrokem jiné postavy románu. Všechny tyto poznámky týkající se charakteristiky osob a některých detailů nacházíme uplatněny v textu románu, a to nezřídka doslovně. Např́iklad jeden z českých tentáků (tedy stavěčů cirkusového stanu neboli tentu), dobrodruh Ferenc Vosátka, je popsán následovně: „Hubený chlap, špinavě červená košile, velká lysina nad čelem, půl pravého ucha pryč, odtud jizva přes celou tvář až k nosu. Na pravé ruce chybí malíček a půl prsteníku“ (IBID.: 265).

Potud tedy autorova dochovaná literární pozůstalost. K okolnostem vzniku románu jsme tedy odkázáni na pamětnická - často protichůdná, navzájem se vylučující - svědectví.

Bassův někdejší redakční kolega Bedřich Golombek dokládá v textu Za oponou manéže (GOLOMBEK 1955), že první vydání mělo vyjít v sešitech v Knihovně Lidových novin. Bass údajně dodával postupně sazárně rukopis a dostával zálohy. Kniha měla začít vycházet, polovina jí byla vysázena. Pak však byla náhle dodávka rukopisu porušena, Bass byl nucen přestat psát kvůli akutnímu zhoršení svého zdravotního stavu. Po několika měsících se sice vzpamatoval, ale protože některé podrobnosti z vysázené části zapomněl, byla mu rychle pořízena kopie textu, který již napsal.

Oproti tomu Ladislav Khás (KHÁS 1957) o dva roky později v Novém životě uvedl, že jakkoliv Bass za okupace nebyl členem redakce Lidových novin, ${ }^{2}$ měl nakladatelský závazek vydat knihu. Původně chtěl napsat novelu ze staré Prahy o nevydařeném kandidátu svatosti. Domníval se ovšem, že by toto bezbožné

2) Toto tvrzení neodpovídá přesně skutečnosti. Bass byl sice záhy po okupaci zbaven šéfredaktorského postu, avšak oficiálně byl veden jako člen redakce až do roku 1941. 
téma neprošlo cenzurou, a proto přistoupil $\mathrm{k}$ dlouho sněnému a obávanému románu. Byla polovina roku 1940, kdy Bass pobýval na letním bytě v jihočeském Protivíně, kde měl na práci dost času. Přes léto prý napsal knihu jedním tahem o 739 tiskových stranách, což je přesně rozsah prvního vydání.

Chceme-li se tázat po zdroji Bassovy fabule, pak podle Antonína Novotného (NOVOTNÝ 1954) jím byly paměti voltižéra (tedy akrobatického jezdce na koni) Ignáce Pecivála, na něž ve vlastních pamětech a ve Zlaté Praze v roce 1917 upozornil Alois Jirásek. Reálným předobrazem cirkusu Humberto pak měl být Beránkův cirkus. Regionální historik Ondřej Kryštof Kolář nám v e-mailové korespondenci sdělil, že Eduard Bass jezdil na konci třicátých let na letní byt Smetiprach na Otavě severně od Písku. Již nefungující mlýn přestavěli v roce 1928 noví majitelé, manželé Filipovi, na výletní restauraci a penzion, který si oblíbily především pražské umělecké kruhy. Po večerech hosté v restauraci naslouchali vyprávění mlynářova bratra, který líčil zážitky z mnohaletého působení u cirkusu (konkrétně pracoval jako tenták). Právě jeho příhody by mohly být primárním zdrojem Bassovy umělecké inspirace. (E-mail z 10. 8. 2018) Některé zdroje dokonce uvádějí, ${ }^{3}$ že Bass strávil s cirkusem dva roky, aby dokonale poznal jeho poměry, osazenstvo, jeho vyjadřování atp. Podle autorova nedávno zveřejněného dopisu (M. Š.: 2005) z 20. prosince 1941 adresovaného českému artistovi Ludvíku Miserovi, působícímu v Berlíně, jsou všechny osoby a děje vymyšleny, včetně dynastie humbertovské. S jedinou historicky doloženou výjimkou, kterou představuje v románu značně idealizovaná postava autority německého cirkusáctví Eduarda Wollschlägera. Dále autor uvádí, že nikdy u cirkusu nebyl, celý text je výsledkem vnějšího studia. Ostatně již v uvedeném prologu k souboru Lidé z maringotek prozaik přiznal, že v záplavě děkovných dopisů, které obdržel po vydání románu, se neustále opakovala otázka, kde k námětu přišel a jak dlouho žil u cirkusu. Na tuto otázku odpovídá Bass poměrně jednoznačně: „[...] umělci není třeba provozovati řemeslo, aby dovedl zachytit jeho svébytné prostředí“ (BASS 1963: 23).

Bohužel se nedochovaly dokumenty poukazující na způsob, jakým na román reagovala nacistická cenzura, snad s výjimkou vyloženě úsměvné vzpomínky Edmonda Konráda (KONRÁD: 1956), poukazující na tragikomičnost tehdejší cenzurní praxe. Při vydávání nastal prý problém s cirkusovým kozlem, který měl původně červenou bradku, tudíž se mu říkalo Rudovous neboli Barbarossa. Ale protože se kozel nemohl přirozeně jmenovat stejně jako slavný císař německé Svaté říše římské, byl Bass přinucen přejmenovat jej na Modrovouse.

3) Jedná se převážně o publicistické stati z druhé poloviny čtyřicátých let a následující dekády 20. století. 


\section{Dobová kritika}

Soudobá kritická recepce Cirkusu Humberto byla poměrně bohatá, obzvláště ve srovnání $\mathrm{s}$ jinými významnějšími literárními texty vydanými $\mathrm{v}$ protektorátní době. Množství dobových recenzí dostatečně prokazatelně dokládá, že literárně kritická diskuse byla přes stísněné publikační možnosti ještě v roce 1941 možná. Přestože se k románu vyslovili kritici ze zcela odlišných ideových pozic a příslušející $\mathrm{k}$ různým literárním uskupením, téměř všichni se shodli na pozitivním přijetí a vysokém ocenění Bassova díla. Při zasazování románu do dobového kontextu byla nejčastěji zmiňována próza Jaroslava Bednáře Bílý smích (1940), rovněž z cirkusového prostředí, dále nepřekvapivě Kožíkův první biografický román Největší z pierotů (1939) a poslední próza Heleny Malířové Mariola (1940). V hledání domácích literárních tradic, na něž svou románovou poetikou Bass navazoval, se kritici shodli na prozaické tvorbě Karla Matěje Čapka-Choda, především pro důkladnou znalost a šíři zobrazeného prostředí.

Václav Černý hned v první větě své recenze v Kritickém měsíčníku bez skrupulí napsal, že Cirkus Humberto není vtělením románové dokonalosti (ČERNÝ 1941a: 245). A to $z$ toho důvodu, že do dvou třetin je historií cirkusu a v poslední třetině historií pražského varieté. Jde tedy podle kritika o kontaminaci dvou přiběhů, v nichž se vyměnily dějiště, prostředí, problémy a ve značné míře i postavy př́běhů, které jsou spojeny jen společným jménem Humberto a osobou Václava Karase. Stejně tak to údajně není próza vynikající sevřeností, hutností a dějovou ani stylovou úsporností. Dále románu recenzent vytýká sentimentálnost, sklon $\mathrm{k}$ idyličnosti a potřebu happyendů. Všechny postavy jako by byly známé, dané, předem hotové. Takovou výstavbu postav pokládá Černý za figurkářství, nikoliv za psychologii. Přesto přese všechno čteme podle kritika prózu s rozkoší, protože před námi objevuje neznámý svět, který autor zná do poslední nitky. Největší hodnota románu tedy spočívá v úplnosti a poznání cirkusového světa.

Již v říjnu roku 1941 Černý svoje hodnocení vcelku výrazně revidoval, když psal sumarizující stat’ Rok 1941 v krásné próze (ČERNÝ 1941b). Tehdy se zaměřil na jiný aspekt Bassovy prózy, když na ní ocenil pečlivost a svědomitost tvořivé práce a vyzdvihl poctivost její umělecké morálky. Román podle kritika

4) Bass si nechal platit výstřižkovou službu ČTK a všechny zmínky o románu si pečlivě a systematicky ukládal, jak můžeme soudit $\mathrm{z}$ jeho pozůstalosti uložené v Literárním archivu Památníku národního písemnictví. V příslušném kartonu lze napočítat přes padesát položek, ale v převážné většině se jedná o anotace či oznámení o vydání. Nacházíme mezi nimi kvanta dojemných čtenářských dopisů, a to i v regionálních listech, které vyjadřují přání, aby se román pro svoji výchovnou funkci dostal do rukou mladých čtenářů, obzvláště chlapců. 
zůstane v naší próze trvalým vzorem toho, čeho se jí nedostává: „Autorů, kteří naprosto vědí, o čem píší, a ovládají svůj svět odbornicky dokonale“ (IBID.: 19). Spolu s prózou Jaromíra Johna Moudrý Engelbert a Čepovou povídkovou knihou Tvár̆ pod pavučinou patři podle Černého Bassův román k žánrovým vrcholům roku 1941, odlišujícím se od většinové prozaické produkce tím, že nejsou ani v nejmenším tezovité.

V téže ročence označil Cirkus Humberto za nejlepší prózu roku rovněž Jaroslav Červinka (ČERVINKA 1941), když jej charakterizoval jako „cirkusáckou epopej“ či „opravdu románové veledílo“. Širokou oblibu si podle něj Bassova kniha získala pro svoji vypravěčskou poutavost a schopnost vyvolávat ve čtenáři snadnou identifikaci s Vaškem Karasem. Chválou nešetří ani Jaroslav Janoušek (JANOUŠEK 1941) v časopise s dobově příznačným názvem Aktivisté. Bassova próza prý vyniká „mohutnou epickou klenbou vyzrálé práce“ a představuje „nesporné obohacení české prozaické produkce“, její autor dokonce vyzvedl český román ze „selankovité okresní malosti na vyšší stupeň světovosti“. A to přestože si na něm recenzent povšiml občasné pražské bodrosti haškovského ražení a nezamýšlené parodičnosti. Příznačně pro časopis, v němž byla recenze publikována, mu imponuje, že „všichni ti hrdinové jsou pevných forem, aktivističtí chlapi, kteří čelí životním nárazům tváří v tvářc (IBID.: 5).

Oproti tomu Jan Blahoslav Čapek (ČAPEK 1941) v Naší době píše o „plošnosti“ Bassových cirkusáků, o př́lišné idealizaci a atmosféře bodré pohody, která prý zdaleka neodpovídá skutečnému cirkusovému životu té doby. Recenzent dále vyčítá románu „sypkost“ děje, „který je rozdroben ve shluky epizod a rozbíhá se v nesčetné závity a odbočky“ (IBID.: 182). Nevyváženosti románového celku pak odpovídá i stylizace různých druhů mluvy, která je u některých postav velmi zdařilá, u jiných jde naopak o nevěrohodnou literarizaci. Stejně jako většina ostatních si také Čapek cení bohaté románové látky, především k sociálním dějinám českého lidu 19. století. Josef Knap v recenzi příhodně nazvané Román o chudém hochu, který se proslavil (KNAP 1941) přitakává Čapkovi, když píše o „vlastenecké polevě“, kterou autor opatřil většinu scén a osudů, aby se zavděčil většinovému čtenáři, avšak o jazyce Bassových postav má - stejně jako většina dalších kritiků - naopak vysoké mínění.

Básník Václav Renč ve své recenzi pro katolický Řád (RENČ 1941) vnímá Cirkus Humberto na pozadí tendence moderního románu odklánějícího se od formalismu a experimentátorství k pravé oblasti epiky. Tou má být dějovost, prostý, až kronikářský způsob vyprávění, přednost látky před formou a návrat k realismu. Přesně této nejprostší zásady se romanopisec Bass údajně držel a naplnil 
tak úspěšně zjednodušený recept realismu, který zní: „Piš o tom, co znáš, napiš to tak, jak to vidíš, a snaž se, aby čtenář viděl to, co líčíš, stejně, jakos to viděl ty“ (IBID.: 447). Také Karel Sezima (SEZIMA 1941) oceňuje Bassovu výbornou znalost cirkusáckého prostředí a ve shodě s předchozí kritikou vytýká románu v některých pasážích žurnalistickou povrchnost a rutinu. $\mathrm{Z}$ hlediska námětu srovnává Sezima Bassovu knihu s prózou francouzského prozaika Edmonda de Goncourta Bratři Zemgano (1879). ${ }^{5}$ Bass proti tomuto naturalistovi působí více kvantitou všeho, „hrne širé záběry detailů, jež neutkvívají nadlouho, nýbrž unikají svou mechanickou nevýrazností“ (IBID.: 144). Bassův postoj se zdá kritikovi bezprostřednější a živočišněji lidský, český prozaik klade mnohem větší důraz na psychologii celého cirkusového kolektivu.

Recenze Bohumila Polana (POLAN 1964) se zdráhá prrímo hodnotit a spokojuje se s pouhou deskripcí. Žánr hodnotí Polan vysoko, když jej charakterizuje jako román-řeku, větvitý epický veletok, ba dokonce jako „mrakodrap kronikářského monumentu s plemennými vlastnostmi fabulačního ducha a psychologické zkušenosti“ (IBID.: 188). Ve shodě s většinou recenzentů Polan píše, že největší dojem učiní román na čtenáře bohatstvím a extenzitou reálných vědomostí o cirkusovém prostředí. Zdaleka největší pochopení pro Bassův román projevil František Götz (GÖTZ 1941) ve své obsáhlé kritice otištěné v Národních listech. „S výjimkou šedivé nehybné plošky“ v druhé části románu nenachází v Cirkusu Humberto jediné slabší místo a všechny textové roviny včetně celistvosti děje, charakteru postav a jejich řeči hodnotí velmi pozitivně. $O$ tom ostatně svědčí závěrečná věta jeho textu: „První nápor Ed. Basse do čiré oblasti epické skončil tedy rozhodným vítězstvím“" (IBID.: 3).

Kromě Černého bezprostřední kritiky a Čapkovy recenze tedy dobová kritika vnímala Bassův román jako velkou (rozsahem i významem), dějově nabitou epiku, opakuje se žánrové označení epopeje či kroniky. Všichni recenzenti poukazují spíše na extenzitu Bassova vyprávění než na jeho vnitřní soudržnost a oceňují autorovu dokonalou znalost látky, tedy cirkusáckého prostředí. ${ }^{6}$ Zmiňují-li se vůbec o postavách, vnímají je jako jednoznačně profilované figury, které jsou mnohem spíše nositeli jedné výrazné vlastnosti nebo charakterového rysu než psychologicky prokreslenými a barvitými aktéry. Svou partikulárností se podílejí na panoptikálnosti cirkusového „sboru“ a ve svém součtu vytvářejí kolektivního hrdinu se svým pevně daným místem a funkcí v jeho řádu a hierarchii.

5) Obdobně tak ve své recenzi činí František Götz (GÖTZ 1941).

6) Jaroslav Kunc dokonce konstatoval, že prokreslení cirkusového prostředí je „bez vady“a že by Bassův román mohl sloužit jako učebnice pro všechny profese s tímto prostředím spjaté. Viz KUNC 1941. 
Spíše jako kuriozitu, byt๋ dobově příznačnou, připomínáme poznámku (VELKÉ MLČENÍ 1942) v nechvalně proslulém antisemitském týdeníku Árijský boj. Nepodepsaná stat’ nazvaná Velké mlčení autora Cirkusu Humberto s pohoršením komentuje úspěch Bassova románu v obou úvodem zmíněných anketách. Jeho autora označuje za exemplární příklad „mlčící sfingy“, rozuměj spisovate(1) le, který, přestože je spjat s odsuzovaným režimem „židomilské“ a „zednářské“ první republiky, působí dosud ve veřejné sféře, aniž by prošel „očistným ohněm“, tedy přiznal se $\mathrm{k}$ minulým omylům. Takové velké mlčení, do něhož se někdejší exponent masarykovské demokracie zahaluje, mu údajně má poskytnout alibi. Obdobně lustračním zpo̊sobem jsou v článku uváděna jména některých účastníků ankety Kniha roku, kteří pro Bassův román hlasovali. Anketa Lidových novin autora článku pohoršuje o to více, že její majitel a členové redakce byli údajně židé a sám Bass byl ve třicátých letech jejím šéfredaktorem. Článek je ukončen karatelským pozdvižením prstu, který je pro kolaborantský časopis příznačný: „Kdo chce mlčet, má jít do kláštera, a nikoliv do novin, které mají býti živým odrazem snah českého národa“" (IBID.: 3).

\section{Univerzálnost češství}

Hned na úvodních stranách románu je opakovaně vyzdvihována univerzálnost příslušníků českého národa, kteří se ve světě neztratí, každý si jich váží pro jejich pracovitost a šikovnost neboli „fortel“. Platí to nejen o Antonínu Karasovi, kterému právě češství otvírá dveře do - pro něj neznámého a obávaného - prostředí cirkusu, ale o všech obyvatelích „české“ maringotky číslo osm. Jako refrén zní zpočátku sentence „Vždyt’ jsi Čech“, jež je vnímána jako schopnost a dovednost lecjakého řemesla, jako by dokládal idiom „šikovné české ručičky“. Obdobně je Anton Karas angažován u cirkusové kapely jako trumpetista, ačkoliv nezná noty. Avšak podle kapelníka Selnického troubí obstojně, protože „co Čech, to muzikant“.

Tato všestrannost se posléze projevuje u Antonova syna Vaška, hlavního hrdiny celého románu, který jako jediný bravurně zvládne hned trojí cirkusácké řemeslo (krotitel, artista, voltižér). Navrací se pak v závěru, kdy už je Vašek dědečkem a zkušeným ředitelem karlínského varieté Humberto. Artisté a kočovní umělci z celé Evropy se k němu sjíždějí na jakési letní cirkusové kurzy a on jim vždy ochotně a rád vypomůže, poskytne radu, všichni jej uznávají jako nezpochybnitelnou autoritu a chtějí znát jeho názor. „Papá Karas“, jak mu přezdívají, bdí jako pohádkový dědeček nad svým „cirkusáckým lidem“. 
Univerzálnost můžeme vnímat i na vyšší rovině, nejen jako vlastnost ústředního aktéra, ale rovněž ve složení osazenstva cirkusu jako celku, který vykazuje prvky nadnárodnosti či přímo internacionálnosti. Vedle mnoha Němců a několika Čechů tu najdeme Poláka, Belgičanku, Nizozemce, Rakušana, Švédy, Španěly, Angličana, Ira či Italy. Avšak evropské národy barvitosti cirkusáků nedostačují: o svého slona pečuje Ind Arr-Šehir, krkolomné artistické kousky předvádí početná tuniská rodina Achmeda Roméa, jehož syn Paolo se stane Vaškovým rivalem usilujícím o přízeň ředitelovy dcery Helenky, Karasovy pozdější manželky.

Cirkus Humberto nejenže má kolektivní duši, jak o něm píše Černý, ale jedná se doslova o unanimistické pojetí dokonale kooperujícího kolektivu lidí. O bezchybně fungující organismus, v němž má každá částečka svoje nezastupitelné místo. Každý člen bez výjimky se s cirkusem Humberto vyloženě identifikuje, dýchá pro něj a považuje jej za „rodinnou instituci“ (BASS 1964: 435).

\footnotetext{
„Každý z nich uměl bezvadně svou věc, ale především se cítili silní jako mužstvo. A Vašek to měl $\mathrm{v}$ sobě tak vryto, že věřil především v tu vzájemnou soudržnost, byl přesvědčen, že i jeho osobní výkony jsou větší a závažnější, protože je nedělá jen ze sebe, nýbrž i z důvěry těch druhých a z harmonie s nimi“ (IBID.: 396).
}

Smysl pro soudržnost, nadřazování kolektivní identity nad individuální, je dobře patrné ve chvíli, kdy Vašek uvažuje nad významem svého jména a uvědomuje si, že je ve velkém světě téměř neznámý. Všichni totiž znají „jen“ jméno cirkusu, jehož je Karas ztělesněním, což ovšem Vaškovi ani v nejmenším nevadí. Vždyṫ už se pro cirkus nejednou obětoval, tudíž mu toto „rozpuštění“ jeho jména v cirkusové komunitě není nikterak proti mysli. (Největší obět musel zcela jistě podstoupit, když si proti své vůli musel vzít Helenku Berwitzovou, třebaže slíbil lásku dceři hamburské bytné Růžence.)

Hrdinův vztah ke jménu Humberto je ovšem ambivalentní, ne-li přímo kontradiktorický. Když je situace ohledně další existence cirkusu kritická, uvede Vašek v rozhovoru s panem Gaudeamem, že je ochoten se vzdát cirkusu, a považuje jej jen za jakousi nálepku: „Má lod’ není tento cirkus Humberto. Můj koráb je můj kumšt, barone, a ten netone“ (IBID.: 366). Na samém závěru protagonista naopak tvrdošijně trvá na tom, že „cirkus Humberto bude žít věčně“ (IBID.: 510), protože jeho vnučka Lidka si zřídila se svým mužem stejnojmennou stáj, což je skutečně patetický happyend. V prvním případě je tedy cirkus Humberto vnímán doslova jako obchodní značka, na níž nezáleží, zatímco vše podstatné, jako jsou umělecké dovednosti, si jedinec nese s sebou bez ohledu na svoji 
příslušnost ke kolektivu. Ono vnitřní se tu pak ocitá v rozporu s vnějškovým označením cirkusu Humberto, $\mathrm{k}$ němuž Vašek lne $\mathrm{v}$ závěru románu a můžeme jej jistě považovat za vyslovení naděje jdoucí nad rámec textu.

Vašek Karas představuje typ hrdiny protektorátní prózy (stejně jako protagonista Kožíkova zmíněného románu), který rezignuje na veřejný život a před osobním štěstím upřednostňuje práci. Před českou láskou a účastí na českém kulturním a politickém životě dal přednost německy mluvící nevěstě a kariéře v nadnárodním, především německém prostředí. Ačkoli češství a vlastenectví je dominantním tématem románu, v plánu ústřední postavy je vlastně oslabeno.

\section{Němectví jako momentálně vládnoucí element}

Přes zjevnou oslavu českého charakteru nesmíme zapomínat, že cirkus představuje německý podnik s trvalým sídlem v Hamburku, odkud každoročně vyjíždí se začátkem sezony na evropské turné. Přestože ve jménech a vlastnostech obou ředitelů - tchána Petra Berwitze a zetě Vaška Karase - můžeme vnímat na jedné straně německou tvrdost, pýchu a rozkazovačnost a na straně druhé českou měkkost, laskavost a pokoru, v žádném případě se nejedná o konkurenci či dokonce o řevnivost dvou národů. Naopak, zmínky o německém původu většiny členů cirkusu a němčiny jako dorozumívacího jazyka mezi nimi jsou minimalizovány, vše je podřízeno participaci všech zaměstnanců na výsledné podobě díla, které má být co nejdokonalejší.

Přesto je do př́běhu zakódováno sdělení o tom, že Češi jsou národ, který si zaslouží svoji existenci, který se Němcům nejenže vyrovná, ale v mnohém je zcela předčí. Nemíníme tím ani tak prostý fakt, že Vašek je mnohem úspěšnější a oblíbenější ředitel než Berwitz, kterého ve funkci nahradil, byṫ se to stalo proti jeho vůli, nikoliv z vypočítavosti. Ve vedení cirkusu se totiž během čtyř generací vystřídaly tři rody odlišných národností: Ital Carlo Humberto - Němci Bernhard a Petr Berwitzové - Čech Václav Karas. Taková triáda by mohla být při troše spekulativního výkladu považována za názornou beletrizaci myšlenek Johanna Gottfrieda Herdera týkajících se filozofie evropských dějin. Podle německého myslitele druhé poloviny 18. století náležela evropská minulost románskému živlu, Herderova současnost patří prvku germánskému a budoucí vývoj Evropy má být ovládán slovanskými národy. ${ }^{7}$ Tomu přesně odpovídá generační výměna

7) K tématu nejnověji v češtině BOJDA 2015, obzvláště kapitola Národnost a všelidskost, s. 539-563. 
vedoucího cirkusu Humberto. Tímto způsobem se Bass mohl navrátit k bazálnímu zdroji českého národního obrození, jakým Herderovy Ideje k filozofii dějin lidstva (1784-1791) bezpochyby byly. Tato analogie má svoje opodstatnění, vždyt tak jako v devatenáctém století si Češi museli svoji existenci doslova vyvzdorovat na mocensky silnějším německém národu, $v$ době protektorátu byla situace obdobná a tím bolestnější, že náš národ po krátkém období první republiky svoji samostatnost znovu ztratil ve prospěch německé nadvlády. K obrozenskému hnutí přímo odkazuje postava stavěče Bureše, který patřil v revolučním roce $1848 \mathrm{k}$ radikálním složkám a poté uprchl z vlasti k cirkusu. Vzdělaný Bureš slouží malému Vaškovi jako domácí učitel, recituje mu vlastenecké básně a seznamuje jej s obrozenskými ideály. Když později zdědí v Praze měštanský dům, stojí právě on za Vaškovým návratem do vlasti, když mu dá tip na karlínský podnik, v němž je následně vybudováno varieté.

\section{Apoteóza ideálů}

Pokusme se závěrem vyabstrahovat $\mathrm{z}$ románového textu ctnosti, které jsou v něm bud’ explicitně jmenovány, anebo implicitně vyplývají z jednání ústředních aktérů. Na předním místě jsou to sounáležitost a soudržnost, pracovitost, houževnatost a disciplinovanost, pokora a úcta k druhým. Podle Jiř́ho Opelíka $\mathrm{k}$ nim dále náleží vytrvalost, perfekcionismus a odpovědnost, činorodost a schopnost kooperace (OPELÍK 2016: 180). Podle kritika Polana zase Karas ztělesňuje stř́zlivou prostotu, mravní počestnost a nezmarně houževnatou vůli, železně se utvrzující na existenčních těžkostech a překážkách (POLAN 1964: 189).

Všechny tyto jednoznačně pozitivní hodnoty ani zdaleka nepředstavují nové rysy Bassovy tvorby, byly v ní přítomny již od samého počátku a podle řady pamětníků je autor uplatňoval i v profesní práci při řízení pražské redakce Lidových novin. Naprosto tytéž hodnoty totiž nacházíme v mnohem exemplárnější podobě již v „povídce pro kluky malé i velké“, jak zní podtitul Klapzubovy jedenáctky (1922). Fotbalový tým Klapzubovy rodiny představuje velmi obdobného kolektivního hrdinu jako cirkus Humberto, každý jeho člen se s ním ztotožní do takové míry, že není zapotřebí ani uvést jeho jméno, tedy základní identifikační atribut, jímž se jedinec odlišuje od druhého.

Ovšemže v prvních letech existence samostatného Československa měla Bassova prozaická prvotina zcela jiný akcent než začátkem protektorátu. Tehdy 
prozaik poukazoval na schopnost českého národa prosadit se v cizině a za hranice svého nově vzniklého státu vyvést prostřednictvím spravedlivé hry, pravidel fair play jeho etické hodnoty. Jedině pracovitostí a sounáležitostí lze totiž uspět a zaujmout důstojné místo mezi evropskými národy. V případě Cirkusu Humberto vlastně také česká skupina tentáků operuje za hranicemi své tehdejší vlasti, Rakousko-uherské monarchie, avšak uchovává si zde svoji národní identitu, neasimiluje se s německou většinou a udržuje si svoji národní pospolitost v maringotce číslo osm. Jestliže v Bassově debutu se jednalo o ofenzivní export národních hodnotových a povahových rysů, v př́iběhu Cirkusu Humberto jsou tytéž povahové rysy defenzivně zachraňovány a předávány $z$ generace na generaci. $^{8}$

Jakkoliv byly předešlé závěry ve zveřejněných recenzích z pochopitelných důvodů opatrně obcházeny a nahrazovány méně nebezpečným konstatováním, čeští čtenáři Bassovu apoteózu českých vlasteneckých ideálů bezpochyby rozpoznali. Především tím si román, formou ani obsahem nikterak objevný, vydobyl obrovskou čtenářskou popularitu nejen v protektorátních letech.

\section{Prameny}

\section{BASS, Eduard}

1964 [1941] Cirkus Humberto (Praha: Československý spisovatel)

1963 [1942] Lidé z maringotek (Praha: Státní nakladatelství krásné literatury a umění)

1985 Moje kronika, eds. Marie Krulichová a Milena Vinařová (Praha: Československý spisovatel)

\section{LITERATURA}

BOJDA, Martin

2015 Herderova filosofie kultury. Herder a německé osvícenství (Praha: Togga)

ČAPEK, Jan Blahoslav

1941 „Literatura“, Naše doba 49 , č. 3, s. 181-183

\section{ČERNÝ, Václav}

1941a „Eduard Bass: ,Cirkus Humberto“', Kritický měsíčník 4, č. 5-6, s. 245-247

1941b „Kritik soudí prózu 1940/1941. Rok 1941 v krásné próze“, in Česká kniha 1941. Vánoční ročenka

8) Dobře patrná je tato proměna ve filmové adaptaci Klapzubovy jedenáctky režiséra Ladislava Broma z roku 1938, v níž vlivem tehdejší politické situace došlo k aktualizaci oslavy pozitivních hodnot fotbalového týmu (respektive českého národa) právě ve směru obranném. 
Čteme, ed. Jiří Ježek (Praha: Svaz českých knihkupců a nakladatelů), s. 18-20

\section{ČERVINKA, Jaroslav}

„Úroda prózy krásné i naučné“, in Česká kniha 1941. Vánoční ročenka Čteme, ed. Jiří Ježek (Praha: Svaz českých knihkupců a nakladatelů), s. 41-43

GOLOMBEK, Bedřich

1955 -bg-: „Za oponou manéže“, Host do domu 2, č. 8, s. 371

GÖTZ, František

1941 „Román z cirku“, Národní listy 18. 4. 1941, 81, č. 107, s. 3-4

JANOUŠEK, Jaroslav

1941 „Letmá přehlídka několika románü“, Aktivisté 4, č. 3, s. 5

KHÁS, Ladislav

1957 „Jak se stavěl Cirkus Humberto“, Nový život, č. 9, s. 984-987

KNAP, Josef

1941 „Román o chudém hochu, který se proslavil“, Venkov 10. 8. 1941, 36, č. 187, s. 7

KONRÁD, Edmond

1956 „Když kozel, tak modrovous (Vzpomínka na Eduarda Basse)“, Zemědělské noviny 29. 9. 1956, 12, č. 236, s. 4

KUNC, Jaroslav

1941 „Rok české krásné prózy“, Knihy a čtenáři 4, č. 16, s. 241-243

M. ̌́.

2005 „Neznámý dopis Eduardu Bassovi“, Masarykův lid 11, č. 3, s. 34

NOVOTNÝ, Antonín

1954 „Od skutečnosti k románovému zpracování“, Lidová demokracie 2. 5. 1954, 10, č. 104, s. 4

OPELÍK, Jiří

2016 „Škola Lidových novin“, in Uklizený stůl aneb Moje druhá knižka o Karlu Čapkovi a opět sjedním př́ivažkem o Josefovi (Praha: Torst), s. 109-204

POLAN, Bohumil

1964 [1941] „Cirkusový svět Eduarda Basse“, in Život a slovo. Literární studie, medailony, náčrty, glosy (Praha: Československý spisovatel), s. 186-190

RENČ, Václav

1941 Rč: „Úspěšný román Eduarda Basse“, Řád 7, č. 8, s. 446-447

\section{bohemica litteraria}


SEZIMA, Karel

1941 „Román a sbírka povídek“, Čteme 3, č. 11-12, s. 143-145

VELKÉ MLČENÍ

1942 „Velké mlčení autora Cirkusu Humberto“, Árijský boj 3, č. 2, s. 3

(1) WANATOWICZOVÁ, Kristýna

2013 Miloš Havel. Český filmový magnát (Praha: Knihovna Václava Havla)

Doc. Mgr. Erik Gilk, Ph.D.,erik.gilk@upol.cz, Katedra bohemistiky, Filozofická fakulta Univerzity Palackého v Olomouci, Česká republika / Department of Czech Studies, Faculty of Arts, Palacky University Olomouc, Czech Republic 